\title{
EXTRACTION CELLULOSE FROM RICE HUSK
}

\author{
Muhammad Arham Yunus ${ }^{1 *}$, Indah Raya ${ }^{1}$, Maming $^{1}$ and Zulkifli I. Tuara ${ }^{1}$ \\ ${ }^{1}$ Department of Chemistry, Faculty of Mathematic, and Natural Science, Hasanuddin University \\ Makassar 90245, Indonesia \\ Perintis Kemerdekaan Street, Tamalanrea Km 10, Makassar 90245, Indonesia \\ *Corresponding Author: arhamyunus21@gmail.com
}

\begin{abstract}
Abstrak. Selulosa dari sekam padi telah berhasil disintesis. Sekam padi merupakan limbah pertanian yang melimpah dan mempunyai kandungan selulosa yang cukup tinggi. Biokonversi sekam padi menjadi selulosa diawali dengan tahapan proses delignifikasi dan bleaching. Selulosa yang dihasilkan dikarakterisasi menggunakan FTIR dan XRD. Spektra IR menunjukkan puncak serapan yang kuat pada $3444,87 \mathrm{~cm}^{-1}$ yang dikaitkan dengan getaran peregangan $\mathrm{O}-\mathrm{H}$ (ikatan hidrogen antar molekul), puncak serapan pada $1033,85 \mathrm{~cm}^{-1}$ diidentiikasi sebagai peregangan $\mathrm{C}-\mathrm{O}-\mathrm{C}$ yang merupakan ikatan $\beta-1,4$-glikosidik dari selulosa. XRD memperlihatkan ukuran partikel selulosa yaitu 3,44 $\mathrm{nm}$ dan memiliki kristalinitas $58,73 \%$. Hasil ini menunjukkan bahwa selulosa dari sekam padi memiliki karakteristik yang baik.
\end{abstract}

Kata Kunci: Sekam padi, Selulosa, FTIR, XRD

\begin{abstract}
Cellulose from rice husk has been successfully synthesized. Rice husk is an abundant agricultural waste and has a high cellulose content. Bioconversion of rice husk into cellulose begins with the stages of delignification and bleaching. The resulting cellulose was characterized using FTIR and XRD. The IR spectra show a strong absorption peak at $3444.87 \mathrm{~cm}^{-1}$ which is associated with stretching vibrations $\mathrm{O}-\mathrm{H}$ (hydrogen bonds between molecules), an absorption peak at $1033.85 \mathrm{~cm}^{-}$ ${ }^{1}$ is identified as stretching $\mathrm{C}-\mathrm{O}-\mathrm{C}$ which is $\beta$ bond $-1,4$ glycosidic from cellulose. X-ray diffragtogram showed that te cellulose obtained had a particle size of $3.44 \mathrm{~nm}$ and crystallilnity of $58.73 \%$.. These results indicated that cellulose from rice husk had good characteristics.
\end{abstract}

Keywords: Rice Husk, Cellulose, FTIR, XRD

\section{INTRODUCTION}

Indonesia is an agricultural country that is known to have abundant biological natural resources, mainly in agriculture. With this abundance of living natural resources, it is not surprising that there are many kinds of agricultural products produced. One of the abundant agricultural waste in Indonesia is rice husk. Rice husk is a by-product produced from rice mills. Based on data from the Central Bureau of Statistics, rice production in Indonesia in the form of milled dry grain was 75.36 million tons. The production continues to increase each year by 4.51 million tons $(6.37 \%)$. Each kilogram of rice produces an average of 280 grams of the husk or as much as $20 \%$ to $30 \%$ of the weight of dry rice milled, so that the accumulation of rice husk waste on average each year is more than 10 million tons (Danarto et al., 2010).

Rice husk is a hard layer which includes kariopsis which consists of two leaf shapes, namely petal husks and crown husks, where in the rice milling process, the husks Will be separated from rice grains and become waste material or grinding waste. From rice mills it will produce about $25 \%$ of husk, $10 \%$ of bran, and $65 \%$ of rice (Haryadi, 2006).

Rice husk is a lignocellulosic material derived from agricultural waste, which has an abundant presence. Rice husk is one of the biomass that has the greatest chemical 
composition of organic carbon, which is $45 \%$ - 50\%. The high composition of organic carbon indicates that the is al lot of cellulose in the rice husk (Prabawati and Wijaya, 2008). The main component of rice husk is silica (15-17\%) (Leiva et al., 2007; Stefani et al., 2005), other components are cellulose $(35 \%)$, hemicellulose $(25 \%)$, and lignin (20\%) (Shukla et al, 2013). Due to its high cellulose content, rice husks can be used as a source of cellulose and can be used as a material that has benefits.

Cellulose is a material commonly used in several biological-based applications such as cosmetics and medicines, because it is environmentally friendly, easily recycled, and is one of the renewable materials. Cellulose has a chemical structure consisting of $\beta-1.4$ glycosidic. Extracted cellulose is stable, biodegradable, thermal stability (Long et al., 2018), and good crystallinity (Yang et al., 2018). Cellulose also has complex crystalline and amorphous morphological forms. In addition cellulose has interesting properties, such as biocompatible, renewable and can be degraded.

Cellulose from rice husk have been used in many applications including to make cellulose nanoparticles with high fluorescence (Kalitaa et al, 2015), cellulose nanocrystals as reinforce in gelatin hydrogels for drug delivery (Ooia, et al, 2016), cellulose acetate (Das et al , 2014) and using of rice husk cellulose for biomedicine (Shukla et al, 2013). Based on the cellulose content of rice husks, this study was carried out to synthesize and determine the cellulose content of rice husks taken from a rice mill in Makassar, Indonesia.

\section{MATERIALS AND METHODS Materials}

The materials used were rice husk taken from the Maccopa rice mill, Sulawesi Selatan, Indonesia, $\mathrm{NaOH}, \mathrm{NaOCl}$, distilled water, and whatmann paper No. 42.

\section{Methods}

\section{Sample preparation}

$800 \mathrm{~g}$ of rice husk was washed and then dried under the sun. Furthermore, rice husks were ground using a hammer mill to obtain smaller sizes of rice husk. After that, rice husk was sifted with a sieve with a size of 80 mesh to obtain finer rice husk powder.

\section{Delignification}

A total of 10 grams of rice husk powder was put into a $250 \mathrm{~mL}$ beaker and then $12 \% \mathrm{NaOH}$ was added as much as $100 \mathrm{~mL}$. The mixture was then heated at $80{ }^{\circ} \mathrm{C}$ for 3 hours, and stirred with a magnetic stirrer. Next, The mixture was filterred, and the precipitate was washed with distilled water until a neutral $\mathrm{pH}$.

\section{Bleaching}

The delignification residue was put into a $250 \mathrm{~mL}$ beaker, added with $100 \mathrm{~mL}$ of $2.5 \% \mathrm{NaOCl}$ solution, heated at $80{ }^{\circ} \mathrm{C}$, and stirred for 1 hour. The precipitate was filtered and washed with distilled water until a neutral $\mathrm{pH}$ value was obtained. The sediment was left for 1 hour and cellulose extract from rice husk was obtained.

\section{Characterization}

Cellulose was characterized using a FTIR SHIMADZU spectrophotometer, to determine the typical functional groups of cellulose measured at wavelengths between $4000-500 \mathrm{~cm}^{-1}$. The diffragtogram was taken from a XRD-7000-Shimadzu with $\mathrm{Cu}$ $\mathrm{K} \alpha$ radiation filterred high-intensity nickelmonochromatic $(\lambda=0.15418)$ produced at $40 \mathrm{kV}$ and $30 \mathrm{~mA}$. The sample was scanned at a speed of $2^{\circ} /$ minute at an angle of $2 \theta$ between $10^{\circ}-50^{\circ}$.

\section{RESULTS AND DISCUSSION}

\section{Cellulose Extract}

Cellulose extract from rice husk has been obtained by delignification using $\mathrm{NaOH}$ and bleaching using $\mathrm{NaOCl}$. The percentage of cellulose obtained from the results of delignification and bleaching was 
$52.3 \%$. The percentage results obtained were quite large and this showed that lignin and hemicellulose can be degraded quite well, where $\mathrm{NaOH}$ in the delignification process can attack and damage the structure of lignin in the crystalline and amorphous parts and separate hemicellulose. Dissolved lignin was marked black in a solution called black liquor (Safaria, 2013). The delignification products were generally white, but the results obtained are still brown. This finding possibly caused by the residual lignin obtained from depolymerization. The remaining chromophore can be removed by bleaching using $\mathrm{NaOCl}$. The bleaching process aims to purify cellulose without a lot of termination of the cellulose chain. The bleaching process will make the color of the pulp brighter or white (Othmer, 1982) and the bleaching results carried out in the study have made the cellulose color of the rice husk obtained brighter and somewhat white.

\section{FTIR Characterization}

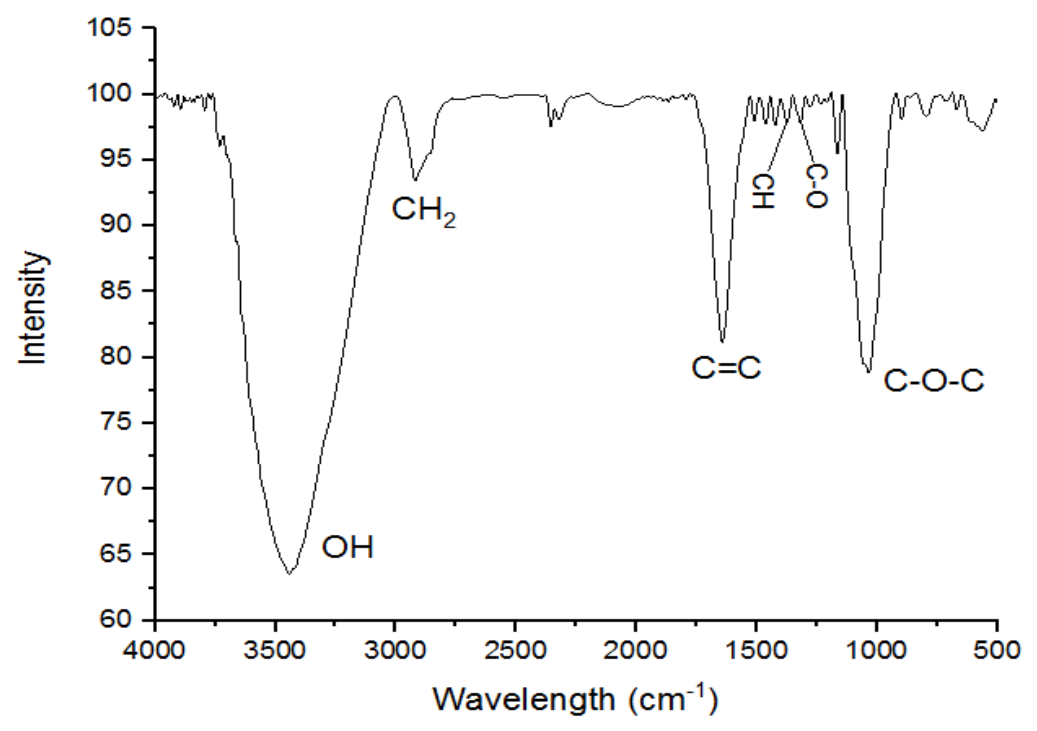

Figure 1. FTIR spectrum of cellulose rice husk 


\section{XRD Characterization}

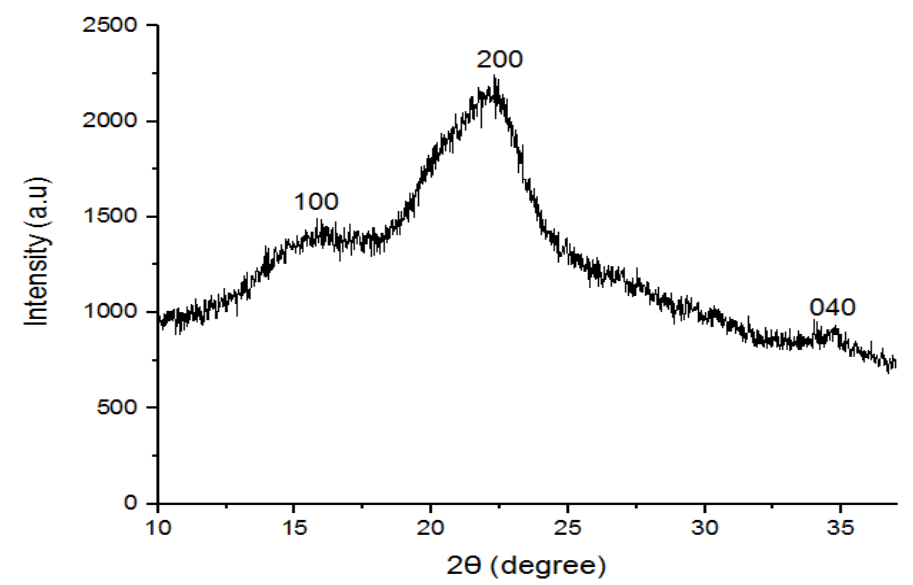

Figure 2. The X-ray diffractogram of cellulose rice husk

The XRD pattern of cellulose is shown in Figure 2. The diffractogram of cellulose from rice husk produced 3 diffraction peaks at angles $2 \theta$ of $17.12^{\circ}$, $22.26^{\circ}$, and $34.48^{\circ}$. The three peaks are related to the crystal fields 110, 200 (Huangzeng, et al., 2015 and Chenling et al., 2017) and 040 (Suryanto, et al., 2017). The XRD pattern shows that the highest peak appears at an angle of $2 \theta$ around 22.26 ${ }^{\circ}$, this area is a typical peak of the cellulose structure. The structure of cellulose was shown by diffraction peaks in the range between $22^{\circ}$ and $23^{\circ}$ and was characteristic of original cellulose (cellulose I) (Le Troedec, et al., 2008).

The crystallinity of cellulose obtained through delignification using $\mathrm{NaOH}$ and bleaching using $\mathrm{NaOCl}$ reaches $58.73 \%$ and amorphous $41,27 \%$. The crystallinity achieved in this study is quite high. The high crystallinity obtained is due to the elimination of hemisellulsoe and lignin in the amorphous region which leads to fatigue in cellulose molecules ( $\mathrm{Li}$ et al., 2009). In addition, the crystal size of rice husk cellulose was $3.44 \mathrm{~nm}$.

\section{CONCLUSION}

Cellulose synthesized from rice husk gives good results in terms of its characterization using FTIR and XRD. The cellulose produced has a high crystallinity of $58.73 \%$ and a very small crystal size of $3.44 \mathrm{~nm}$.

\section{REFERENCES}

Chenglin, H., Jianying, H., Shuhui, L., Kai, M., Liyuan, Z., Zhong, C., dan Yuekun, L., 2017, Mechanically Resistant and Sustainable CelluloseBased Composite Aerogels with Excellent Flame Retardant, SoundAbsorption, and Superantiwetting Ability for Advanced Engineering Materials, ACS Sustainable Chemistry \& Engineering, 6(1), 927-936.

Danarto, Y.C., A. Nur, and E. R. Dyartati., 2010, Adsorption of Heavy Metal Waste with Carbon from Rice Husk in a Permanent Superior Column, Research Report of Young Lecturers in 2006, Department of Chemical Engineering Faculty of Engineering, UNS.

Das. A. M., Ali, A. A., Hazarika, M. P., 2014, Synthesis and characterization of celluloseacetate from rice husk: Eco-friendly condition, Carbohydrate Polymers, 112: 342349.

Haafiz, M.M.K., Eichhorn, S.J., Hassan, A., Jawaid, M., 2013, "Isolation and Characterization of Microcrystalline Cellulose from Oil Palm Biomass 
Residue", Carbohydrate Polymers, 93, 628-634.

Haryadi. 2006. Rice Processing Technology. Jakarta. Gajah Mada University Press.

Huazheng, S., Rui, F., Li, X., Junhui, X., Zhenyou, L., Fei, L., and Ting, Z., 2015, Surface Modification of Bacterial Cellulose Aerogels' Weblike Skeleton for Oil/Water Separation, ACS Applied Materials \& Interfaces, 7, 7373-7381.

Jahan, M. S., Saeed, A., He, Z., Ni, Y., 2011, Jute as Raw Material for the Preparation of Microcrystalline Cellulose, Cellulose, 18, 451-459.

Kalitaa, E., Natha, B.K., Debb, P., Agana, F., Islama, Md. R.,Saikia, K, 2015, High Quality Fluorescent Cellulose Nanofibers From Endemic Rice Husk: Isolation an Characterization. Carbohydrate Polymers, 122: 308313.

Leiva, P., Ciannamea E. M., Ruseckaite R. A., dan Stefani P. M, 2007, MediumDensity Particleboards from Rice Husks and Soybean Protein Concentrate, J. Appl. Polym. Sci. 106, 1301-1306.

Le Troedec, M., Sedan, D., Peyratout, C., Bonnet, J.P., Agnes, S., 2008, Influence of various chemical treatments on the composition and structure of hemp fibres, Compos Part A, 39, 514-522.

Li, W., Yue, J., Liu, S., 2012, Preparation of Nanocrystals Cellulose via Ultrasound and its Reinforcement Capability for Poly (vinyl alcohol) Composites, Ultrasonic Sonochemistry, 19, 479-485.

Long, Y., Weng, X., dan Wang, Z., 2018, Cellulose Aerogels: Synthesis, Applications, and Prospects, Polymers. 6: 6-23.

Ooia, S. Y., Ahmada,I., Cairul Iqbal, M. C., Amin, M., 2016, Cellulose Nanocrystals Extracted From Rice Husks As A Reinforcingmaterial In Gelatin Hydrogels For Use In
Controlled Drug Deliverysystems, Industrial Crops and Products, 93: 227-234.

Othmer, K., 1982, Encyclopedia of Chemical Technology"3th edition, Canada: John Wiley and Sons.

Shukla, S.K., Nidhi, Sudha, Pooja, Namrata, Charu, Akshay, Silvi, Manisha, Rizwana, Bharadvaja, A., and Dubey, G. C., 2013, Preparation and Characterization of Cellulose Derived from Rice Husk for Drug Delivery, Adv. Mat. Lett, 4 (9), 714 719.

Stefani, P. M., Garcia, D., Lopez, J., Jimenez, A., 2005, Thermogravimetric Analysis of Composites Obtained from Sintering of Rice Husk-scrap Tire Mixtures, Journal Therm. Anal. Calorim, 81. 315-320.

Suryanto, H., Irawan, Y.S., Marsyahyo, E., Soenoko, R., 2017, Effect of Alkali Treatment on Crystalline Structure of Cellulose Fiber From Mendong (Fimbristylis globulosa) Straw. Key Eng. Mater, 594-595, 720-724.

Prabawati, S. Y and Wijaya, A. G., 2008, Utilization of Rice Husk and Banana Tree Midribs as Alternative Materials for Making Quality Paper, Aplikasia, IX. 1. $44-56$.

Yang, S., Lu, X., Zhang, Y., Xu, J., Xin, J., dan Zhang, S., 2018, Separation And Characterization Of Cellulose I Material From Corn Straw by LowCost Polyhydric Protic Ionic Liquids, Cellulose, 25 (6): 32413254.

Yu, H., Qin, Z., Liang, B., Liu, N., Zhou, Z., Chen, L., 2013, "Facile Extraction of Thermally Stable Cellulose Nanocrystals with a High Yield of 93\% Through Hydrochloric Acid Hydrolysis under Hydrothermal Conditions, Journal of Materials Chemistry A, 1, 3938-3944. 